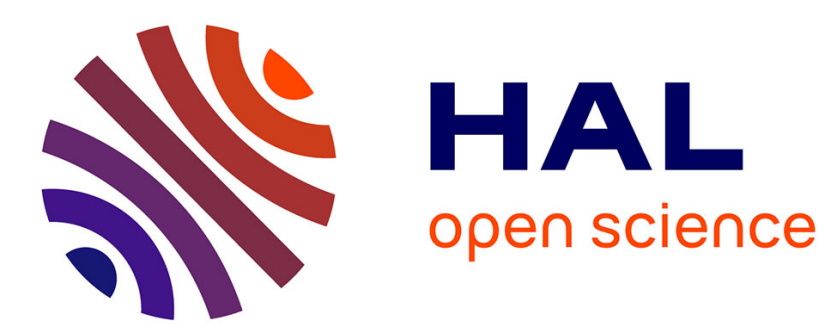

\title{
Dependence of default probability and recovery rate in structural credit risk models: Case of Greek banks
}

\author{
Abdelkader Derbali, Lamia Jamel
}

\section{To cite this version:}

Abdelkader Derbali, Lamia Jamel. Dependence of default probability and recovery rate in structural credit risk models: Case of Greek banks. Journal of the Knowledge Economy, In press, 10.1007/s13132-017-0473-1 . hal-01695998

\section{HAL Id: hal-01695998 \\ https://hal.science/hal-01695998}

Submitted on 30 Jan 2018

HAL is a multi-disciplinary open access archive for the deposit and dissemination of scientific research documents, whether they are published or not. The documents may come from teaching and research institutions in France or abroad, or from public or private research centers.
L'archive ouverte pluridisciplinaire HAL, est destinée au dépôt et à la diffusion de documents scientifiques de niveau recherche, publiés ou non, émanant des établissements d'enseignement et de recherche français ou étrangers, des laboratoires publics ou privés. 


\title{
Dependence of default probability and recovery rate in structural credit risk models: Case of Greek banks
}

\author{
Abdelkader Derbali* \\ Higher Institute of Management of Sousse, \\ Department of Finance, University of Sousse, Tunisia \\ 22 street Zarkaa Al Yamama, Erriadh City, Sousse 4023 \\ Email: derbaliabdelkader@outlook.fr \\ *Corresponding author \\ Lamia Jamel \\ Faculty of Economic Sciences and Management of Sousse, \\ Department of Economics, Sousse University, Tunisia \\ Email: lajamel@yahoo.fr
}

\begin{abstract}
The main idea of this paper is to examine the dependence between the probability of default (PD) and the recovery rate (RR). For the empirically methodology, we use the bootstrapped quantile regression and the simultaneous quantile regression for a sample of 17 Greece banks listed in Athens Exchange over the period of study from January 02, 2006 to December 31, 2012. The measurement of this dependence is determinate by using 7 indicators such as; the probability of default, the recovery rate, the number of defaults, the expected value of losses, the growth rate of GDP in Greece and three dummy variables (the exit of another firm of the Athens Exchange, the new firm is listed in the Athens exchange and the date of the failure of Greece). The main empirical results show that the probability of default and the recovery rate are inversely related. Based on this result, the banks are obliged to maximize their recovery rate to reduce their probability of default.
\end{abstract}

Key words: probability of default; recovery rate; number of default; expected value of losses; bootstrapped quantile regression; simultaneous quantile regression JEL Classification: C14; C15; G12; G21; G32.

Biographical notes: Dr. Abdelkader Derbali is an Assistant Professor in Finance at the Higher Institute of Management of Sousse in University of Sousse, Tunisia. He is one of the Editorial Board Members in African Journal of Accounting, Auditing and Finance, African Journal of Economic and Sustainable Development the Journal of Energy Markets, International Business Review, Energy Economics, Cogent Economic \& Finance, and 
International Review of Applied Economics. His research interests include Risk Management, Systemic risk, International finance, Capital markets and institutions, Banking and market microstructure, Islamic Finance, energy economics, and financial economics. He has published articles, among others, in Research in International Business and Management, Cogent Business \& Management, Cogent Economic \& Finance, Journal of Chinese Governance, The Chinese Economy, Journal of Energy Markets, African Journal of Accounting, Auditing and Finance, International Journal of Economics and Accounting, International Journal of Critical Accounting, and International Journal of Trade and Global Markets.

Dr. Lamia Jamel is a $\mathrm{PhD}$ in Economics at the Faculty of Economic Sciences and Management of Sousse, Tunisia. His research interests include Economic analysis, financial economics, quantitative finance, financial development, and energy commodities. He is one of the Editorial Board Members in the Cogent Economics and Finance, Journal of Chinese Governance, International Journal of Risk and Contingency Management, International Journal of Sustainable Economies Management, International Journal of Food and Beverage Manufacturing and Business Models, and International Journal of Managerial Studies and Research. She has published articles in African Journal of Accounting, Auditing and Finance and in Cogent Economic \& Finance. 


\section{Introduction}

This literature review briefly recapitulates the way credit risk models, which have studied during the last thirty years, treat Recovery Rate and, more specifically, their relationship with the Probability of Default of firm. These models can be divided into two main categories (Atman et al., 2002) such as, Credit pricing models and Portfolio credit value-at-risk (VaR) models.

Thus, credit pricing models can in turn be divided into three main approaches as, "First generation" structural-form models, "Second generation" structural-form models, and Reduced-form models.

These three different approaches, together with their basic assumptions advantages, drawbacks and empirical performance as, First generation structural-form models: the Merton approach, Second generation structural-form models, Reduced-form models, Credit value-atrisk models, and some latest contributions on the PD-RR relationship ${ }^{1}$.

It has been noted that default probabilities and default rates and average recovery rates are negatively correlated (Altman et al., 2005). Then, both variables also seem to be driven by the same common factor that is persistent over time and clearly related to be the business cycle: in recessions or industry downturns, default rates are high and recovery rates are low.

Thus, the main idea for this study is to answer the question follows: As the Probability of Default is depended to the Recovery Rate and conversely. Then, we use the bootstrapped quantile regression and the simultaneous quantile regression for a sample composed of 17 Greece banks listed in Athens Exchange during the period through January 02, 2006 to December 31, 2012. To estimate this dependence, we utilize 7 indicators such as; the probability of default, the recovery rate, the number of defaults, the expected value of losses, the growth rate of GDP in Greece and three dummy variables (the exit of another firm of the Athens Exchange, the new firm is listed in the Athens exchange and the date of the failure of Greece). The main empirical findings demonstrate that the probability of default and the recovery rate are inversely correlated. Based on these findings, the banks are obliged to maximize their recovery rate to decrease their probability of default.

Then, the rest of this paper is structured as follows: The literature review is developed on section 2. The dependence between the probability of default and the recovery rate is presented in section 3 . In section 4 , we describe the data, the econometric methodologies and

\footnotetext{
${ }^{1}$ PD : the Probability of default, RR: The Recovery Rate.
} 
the model used in this paper. Section 5 discusses and analysis of the econometric findings. Finally, the sixth section is considered to conclude.

\section{Literature review}

The main idea of this study is to describe and to determinate the relationship of dependence between probability of default and the recovery rate. In the literature, this dependence is treated by many authors. The table 1 shows the main works that developed and studied the dependence between the PD and the RR.

Table 1: The treatment of the dependence between PD and RR

\begin{tabular}{|c|c|c|c|}
\hline & $\begin{array}{lr}\text { Main } & \text { models } \text { and } \\
\text { related } & \text { empirical } \\
\text { results } & \\
\end{array}$ & Treatment of PD & $\begin{array}{l}\text { Relationship between } \\
\text { PD and RR }\end{array}$ \\
\hline \multicolumn{4}{|c|}{ Credit Pricing models } \\
\hline $\begin{array}{l}\text { First generation } \\
\text { structural-form models }\end{array}$ & $\begin{array}{l}\text { Merton (1974), Black and } \\
\text { Cox (1976), Geske (1977), } \\
\text { Vasicek (1984), Crouhy and } \\
\text { Galai (1994), Jones et al. } \\
\text { (1984). }\end{array}$ & $\begin{array}{l}\text { PD and RR are a function of } \\
\text { the structural characteristics } \\
\text { of the firm. RR is therefore } \\
\text { an endogenous variable. }\end{array}$ & $\begin{array}{l}\mathrm{PD} \text { and } \mathrm{RR} \text { are inversely } \\
\text { related. }\end{array}$ \\
\hline $\begin{array}{l}\text { Second generation } \\
\text { structural-form models }\end{array}$ & $\begin{array}{l}\text { Kim et al. (1993), Nielsen et } \\
\text { al. (1993), Hull and White } \\
\text { (1995), Longstaff and } \\
\text { Schwartz (1995). }\end{array}$ & $\begin{array}{l}\text { RR is exogenous and } \\
\text { independent from the firm's } \\
\text { asset value. }\end{array}$ & $\begin{array}{l}\mathrm{RR} \text { is generally defined as a } \\
\text { fixed ratio of the outstanding } \\
\text { debt value and is therefore } \\
\text { independent from PD. }\end{array}$ \\
\hline Reduced-form models & $\begin{array}{l}\text { Litterman and Iben (1991), } \\
\text { Madan and Unal (1995), } \\
\text { Jarrow and Turnbull (1995), } \\
\text { Jarrow et al. (1997), Lando } \\
\text { (1998), Duffie and Singleton } \\
\text { (1999), Duffie (1998) and } \\
\text { Duffee (1999). }\end{array}$ & $\begin{array}{l}\text { Reduced-form models } \\
\text { assume an exogenous RR } \\
\text { that is either a constant or a } \\
\text { stochastic variable } \\
\text { independent from PD. }\end{array}$ & $\begin{array}{l}\text { Reduced-form models } \\
\text { introduce separate } \\
\text { assumptions on the dynamic } \\
\text { of PD and RR, which are } \\
\text { modeled independently from } \\
\text { the structural features of the } \\
\text { firm. }\end{array}$ \\
\hline $\begin{array}{l}\text { Latest contributions on } \\
\text { the PD-RR relationship }\end{array}$ & $\begin{array}{l}\text { Frye (2000), Jarrow (2001), } \\
\text { Carey and Gordy (2001), } \\
\text { Altman and Brady (2002). }\end{array}$ & $\begin{array}{l}\text { Both PD and RR are } \\
\text { stochastic variables which } \\
\text { depend on a common } \\
\text { systematic risk factor (the } \\
\text { state of the economy). }\end{array}$ & $\begin{array}{l}\text { PD and RR are negatively } \\
\text { correlated. In the } \\
\text { "macroeconomic approach" } \\
\text { this derives from the } \\
\text { common dependence on one } \\
\text { single systematic factor. In } \\
\text { the "microeconomic } \\
\text { approach" it derives from } \\
\text { the supply and demand of } \\
\text { defaulted securities. }\end{array}$ \\
\hline \multicolumn{4}{|c|}{ Credit value at risk models } \\
\hline CreditMetrics® & $\begin{array}{l}\text { Gupton, Finger and Bhatia } \\
\text { (1997) }\end{array}$ & $\begin{array}{l}\text { Stochastic variable (beta } \\
\text { distr.) }\end{array}$ & RR independent from PD \\
\hline CreditPortfolioView® & Wilson (1997a and 1997b). & Stochastic variable & RR independent from PD \\
\hline CreditRisk+® & $\begin{array}{l}\text { Credit Suisse Financial } \\
\text { Products (1997). }\end{array}$ & Constant & RR independent from PD \\
\hline KMV CreditManager $®$ & $\begin{array}{l}\text { McQuown (1997), Crosbie } \\
\text { (1999). }\end{array}$ & Stochastic variable & RR independent from PD \\
\hline
\end{tabular}

\section{Dependence between the probability of default and the recovery rate:} analytical analysis 
By analyzing the previous literature, we can conclude that the default probability was estimated according to several approaches. So, the default probability can be estimated by basing itself on historical series of default by measuring the risk by the rating or the score (Altman, 1968). Empirically, the measures of score call on to alternatives as the analysis in main component, the logistic regression and the Probit analysis.

Jonkhart (1979) deducts the default probability from the spreads of rates available on markets. The works of Jonkhart are carried out by Iben and Litterman (1989), Wu and Yu (1996), Altman (1988, 1989), Asquith et al. (1989), Rosenberg and Gleit (1994), Hand and Henely (1997) and Thomas (2000), who deducted the default probability from historical data on the bonds having been lacking by type of rating and by type of term.

Merton (1979), Black and Scholes, Black and Cox (1976), Geske (1977) and Lee (1981) deducted the default probability from the volatility of assets. This method is intended for the highly-rated credits.

In our paper, we are going to base ourselves on the analysis developed by Merton (1974). So, Merton's model is based on the hypothesis which the company $\mathbf{k}$ has a certain quantity of debt with zero-coupon. The nominal value of this debt is $\mathbf{F}_{\mathbf{k}}$ and it becomes due in the maturity date $\mathbf{T}$. The Firm is declared default if, in the date $\mathbf{T}$, the value of its assets is lower than its nominal value, is, if $\mathrm{V}_{\mathrm{k}}(\mathrm{T})<\mathrm{F}_{\mathrm{k}}$. The recovery rate spells then under the following shape:

$$
R_{k}=\frac{F_{k}}{V_{k}(T)}
$$

And the loss in the case of default is:

$$
L_{k}^{*}=1-R_{k}=\frac{F_{k}-V_{k}(T)}{F_{k}}
$$

By using the function of Heaviside $(\boldsymbol{\Theta})$, we can determinate the loss individual can be expressed by the following form:

$$
L_{k}=\left(1-\frac{V_{k}(T)}{F_{k}}\right) \Theta\left(1-\frac{V_{k}(T)}{F_{k}}\right)
$$

So, in the Merton's model, the losses value and the recovery rate are directly determined by the value of assets to the date of maturity. 
Thus, the stochastic modeling of the market value of a company $V_{k}(T)$ allows to evaluate his credit risk. The probability density function (pdf) of markets values in the date of maturity $\mathrm{P}_{\mathrm{V}_{\mathrm{k}}}\left(\mathrm{V}_{\mathrm{k}}(\mathrm{T})\right)$. So, the default probability is given by:

$$
P_{D, k}=\int_{0}^{F_{k}} P_{V_{k}}\left(V_{k}(T)\right) d V_{k}(T)
$$

And the recovery rate will be calculated as follows:

$$
\left\langle R_{k}\right\rangle=\frac{1}{P_{D, k}} \int_{0}^{F_{k}} \frac{V_{k}(T)}{F_{k}} P_{V_{k}}\left(V_{k}(T)\right) d V_{k}(T)
$$

Let us consider now a portfolio of credit $\mathbf{K}$, where the market value of every company is correlated in one or in several variables. Under the condition of the realizations of variables, we obtain different values of $P_{D, k}$ and of $\left\langle R_{k}\right\rangle$. In fact, we can demonstrate a functional dependence between the probability of default and the recovery rate. This is in contrast with what is evoked by certain surrounding areas of modeling which suppose the existence of an independence of these qualities.

By supposing the existence of a process of underlying distribution of the value of the company, we can easily deduct all the results relative to the measure of the probability of default and the recovery rate.

So, we consider a homogeneous portfolio of size $\mathbf{K}$. The nominal value of this portfolio is $F_{k}=F$ and the first market values are $V_{k}(0)=V_{0}$.

The evolution in the time of the market value of a single firm $\mathrm{k}$ is modeled by a stochastic differential equation of the following form:

$$
\frac{d V_{k}}{V_{k}}=\mu d t+\sqrt{c} \sigma d W_{m}+\sqrt{(1-c)} \sigma d W_{k}
$$

This equation describes a process of correlated diffusion to a determinist term $\mu \mathrm{dt}$ and a correlated linearly diffusion. The parameters of this process are; the constant $\mu$, the volatility $\sigma$ and the correlation $\mathbf{c}$ between the firm return and the market return. The process of Wiener indicated by $\mathrm{dW}_{\mathrm{k}}$ and $\mathrm{dW}_{\mathrm{m}}$, describes the idiosyncratic fluctuations and the market fluctuations respectively. 
So, the evaluation of the prices of the options on the financial market is based on two parameters important to know the volatility and the fluctuations of assets (Gatfaoui, 2006; Giovanni et al., 2012). In this aligned, the fluctuations in the prices of assets are understandable by two different and independent risk factors which are the systematic factor and the idiosyncratic factor.

Therefore, the pricing of assets is improved there because the distortions of the price of the underlying are decomposed into two parts:

- A component of market volatility stemming from systematic fluctuations in the price of asset $\left(\mathrm{dW}_{\mathrm{m}}\right)$.

- A component of idiosyncratic volatility stemming from specific fluctuations in the price of asset $\left(\mathrm{dW}_{\mathrm{k}}\right)$.

For increment of discreet time $\Delta \mathrm{t}=\frac{\mathrm{T}}{\mathrm{N}}$, where the time is divided on $\mathrm{N}$ stages, we arrive at the discreet formulation of the stochastic differential equation above. The market value of $\mathrm{k}$ firms in the maturity can be written in the following form:

$$
V_{k}(T)=V_{0} \prod_{t=1}^{N}\left(1+\mu \Delta t+\sqrt{c} \sigma \eta_{m, t} \sqrt{\Delta t}+\sqrt{1-c} \sigma \varepsilon_{k, t} \sqrt{\Delta t}\right)
$$

With, $\eta_{m, t}$ and $\varepsilon_{k, t}$ are independent random variables and they follow a normal distribution law. We will try in what follows to determine market return $X_{m}$, the number of default $N_{D}\left(X_{m}\right)$ and the recovery rate $\left\langle R\left(X_{m}\right)\right\rangle$. On the market return $\left\langle R\left(X_{m}\right)\right\rangle$ which defines the average yield of all $\mathrm{k}$ firms over a period of time to maturity.

$$
X_{m}=\frac{1}{K} \sum_{k=1}^{K}\left(\frac{V_{k}(T)}{V_{0}}-1\right)=\frac{1}{K} \sum_{k=1}^{K} \prod_{t=1}^{N}\left(1+\mu \Delta t+\sqrt{c} \sigma \eta_{m, t} \sqrt{\Delta t}+\sqrt{1-c} \sigma \varepsilon_{k, t} \sqrt{\Delta t}\right)-1
$$

For $K \rightarrow \infty$, we can express the average on $\mathrm{k}$ as the value of the hope $\varepsilon_{k, t}$. For the independence of $\varepsilon_{k, t}$ for different $\mathrm{k}$ and $\mathrm{t}$, we can write then:

$$
X_{m}+1=\prod_{t=1}^{N}\left(1+\mu \Delta t+\sqrt{c} \sigma \eta_{m, t} \sqrt{\Delta t}+\sqrt{1-c} \sigma\left\langle\varepsilon_{k, t}\right\rangle \sqrt{\Delta t}\right)
$$

With : 


$$
\left\langle\varepsilon_{k, t}\right\rangle=0
$$

Then, the expression of $\boldsymbol{X}_{\boldsymbol{m}}+\mathbf{1}$ will be simplified as follows:

$$
\begin{gathered}
X_{m}+1=\prod_{t=1}^{N}\left(1+\mu \Delta t+\sqrt{c} \sigma \eta_{m, t} \sqrt{\Delta t}\right)=\exp \left(\sum_{t=1}^{N} \ln \left(1+\mu \Delta t+\sqrt{c} \sigma \eta_{m, t} \sqrt{\Delta t}\right)\right) \\
\approx \exp \left(\left(\mu-\frac{c \sigma^{2}}{2}\right) T+\sigma \sqrt{c \Delta t} \sum_{t=1}^{N} \eta_{m, t}\right)
\end{gathered}
$$

In this stage, we apply the logarithm to the function above. The random variable $\eta_{m, t}$ follows a standard normal distribution. Then, we obtain:

$$
\ln \left(X_{m}+1\right)=\left(\mu-\frac{c \sigma^{2}}{2}\right) T+\sigma \sqrt{c T} \frac{1}{\sqrt{N}} \sum_{t=1}^{N} \eta_{m, t}
$$

Thus, the variable $\ln \left(\mathrm{X}_{\mathrm{m}}+1\right)$ is normally distributed with average $\left(\mu T-\frac{c \sigma^{2} T}{2}\right)$ and variance $c \sigma^{2} T$. So, by basing itself on the normal logarithmic distribution, we can write the probability density function as follows:

$$
p_{X_{m}}\left(X_{m}\right)=\frac{1}{\left(X_{m}+1\right) \sqrt{2 \pi c \sigma^{2} T}} \exp \left(\frac{\left(\ln \left(X_{m}+1\right)-\mu T+\frac{1}{2} c \sigma^{2} T\right)^{2}}{2 c \sigma^{2} T}\right)
$$

For a single firm $\mathrm{k}$ we can write:

$$
\begin{array}{r}
\ln \frac{V_{k}(T)}{V_{0}}=\sum_{t=1}^{N} \ln \left(1+\mu \Delta t+\sqrt{c} \sigma \eta_{m, t} \sqrt{\Delta t}+\sqrt{1-c} \sigma \varepsilon_{k, t} \sqrt{\Delta t}\right) \\
\approx \ln \left(X_{m}+1\right)\left(\mu-\frac{c \sigma^{2}}{2}\right) T+\sigma \sqrt{c T} \frac{1}{\sqrt{N}} \sum_{t=1}^{N} \eta_{m, t}
\end{array}
$$

Thus, the market return $X_{m}$ is considered a constant. Thereafter, all variables $\mathrm{V}_{\mathrm{k}}(T)$ are independent and the variable $\ln \frac{\mathrm{V}_{\mathrm{k}}(T)}{\mathrm{V}_{0}}$ is normally distributed and we have an average $\ln \left(X_{m}+1\right)-\frac{(1-c) \sigma^{2}}{2} T$ and a variance $(1-c) \sigma^{2} T$ 
Since, we considered a homogeneous portfolio; we omit the index $\mathrm{k}$ in follows. This allows a better rating and effective results. The probability density function for the market value of a firm is given by the following form:

$$
\begin{aligned}
& P_{v}(V(T)) \\
& =\frac{1}{\left(X_{m}+1\right) \sqrt{2 \pi(1-c) \sigma^{2} T}} \exp \left(\frac{\left(\ln \frac{V(T)}{V_{0}}-\ln \left(X_{m}+1\right)+\frac{1}{2}(1-c) \sigma^{2} T\right)^{2}}{2(1-c) \sigma^{2} T}\right)
\end{aligned}
$$

So, the individual probability of default is given by the following function:

$P_{D}\left(X_{m}\right)=\int_{0}^{F} p_{v}(V(T)) d V(T)=\Phi\left(\frac{\left(\ln \frac{V(T)}{V_{0}}-\ln \left(X_{m}+1\right)+\frac{1}{2}(1-c) \sigma^{2} T\right)^{2}}{2(1-c) \sigma^{2} T}\right)$

Where, $\Phi$ denotes the cumulative standard normal distribution. The expected value of the loss of individual default $L^{*}=1-\frac{V(T)}{F}$ can be calculated as follows:

$$
\begin{array}{r}
\left\langle L^{*}\left(X_{m}\right)\right\rangle=\frac{1}{P_{D}\left(X_{m}\right)} \int_{0}^{F}\left(1-\frac{V(T)}{F}\right) p_{v}(V(T)) d V(T) \\
=\frac{1}{P_{D}\left(X_{m}\right)}\left[\Phi\left(\frac{\left(\ln \frac{V(T)}{V_{0}}-\ln \left(X_{m}+1\right)+\frac{1}{2}(1-c) \sigma^{2}\right)}{\sqrt{(1-c)} \sigma^{2} T}\right)\right. \\
-\exp \left(\ln \left(X_{m}+1\right)\right. \\
\left.\left.-\ln \frac{F}{V_{0}}\right) \Phi\left(\frac{\left(\ln \frac{V(T)}{V_{0}}-\ln \left(X_{m}+1\right)+\frac{1}{2}(1-c) \sigma^{2}\right)}{\sqrt{(1-c)} \sigma^{2} T}\right)\right]
\end{array}
$$

The expected recovery rate is:

$$
\left\langle R\left(X_{m}\right)\right\rangle=1-\left\langle L^{*}\left(X_{m}\right)\right\rangle
$$

In the case of a homogeneous portfolio, the loss of a portfolio (average loss) is obtained by the following form:

$$
\left\langle L\left(X_{m}\right)\right\rangle=P_{D}\left(X_{m}\right)\left\langle L^{*}\left(X_{m}\right)\right\rangle
$$


For clarity, we introduce the function:

$$
A\left(X_{m}\right)=\ln \frac{F}{V_{0}}-\ln \left(X_{m}+1\right)
$$

Where B is the composite parameter which is written as follows:

$$
B=\sqrt{(1-c) \sigma^{2} T}
$$

However, the expressions of $P_{D}\left(X_{m}\right)$ and $\left\langle R\left(X_{m}\right)\right\rangle$ are simplified as follows:

$$
P_{D}\left(X_{m}\right)=\Phi\left(\frac{A\left(X_{m}\right)+\frac{1}{2} B^{2}}{B}\right)
$$

And,

$$
\left\langle R\left(X_{m}\right)\right\rangle=\frac{\mathrm{e}^{-A\left(X_{m}\right) \Phi\left(\frac{A\left(X_{m}\right)+\frac{1}{2} B^{2}}{B}\right)}}{\Phi\left(\frac{A\left(X_{m}\right)+\frac{1}{2} B^{2}}{B}\right)}
$$

The relationship between the probability of default and the recovery rate does not depend on B only, but it is set by $A\left(X_{m}\right)$. Thus, the parameter B can be measured by the probability of default and the recovery rate. In addition, reversing the expression of $P_{D}\left(X_{m}\right)$, we can express $\mathbf{A}$ in terms of $P_{D}$ :

$$
A=B \Phi^{-1}\left(P_{D}\right)-\frac{1}{2} B^{2}
$$

To clarify the effect of the idiosyncratic fluctuations and the market fluctuations on the volatility, Schäfer and Koivusalo (2011) proposed a relationship of functional dependence for the probability of default and the recovery rate. The recovery rate is expressed by the following form:

$$
\left\langle L\left(P_{D}\right)\right\rangle=\frac{1}{P_{D}} \exp \left(-B \Phi^{-1}\left(P_{D}\right)-\frac{1}{2} B^{2}\right) \Phi\left(\Phi^{-1}\left(P_{D}\right)-B\right)
$$


If should be noted that this functional relationship depends on a single parameter B. We can see that for higher values of B lead to an overall decrease in the recovery rate. From the equation above $\left\langle R\left(P_{D}\right)\right\rangle$, we can obtain the functional relationship of the portfolio loss and default probabilities:

$$
\left\langle L\left(P_{D}\right)\right\rangle=P_{D}-\exp \left(-B \Phi^{-1}\left(P_{D}\right)-\frac{1}{2} B^{2}\right) \Phi\left(\Phi^{-1}\left(P_{D}\right)-B\right)
$$

For a high value of $\mathrm{K}(K \rightarrow \infty)$, the idiosyncratic is zero and the market return $X_{m}$ is defined only by the realization of the term $\eta_{m, t}$. The number of default $N_{D}\left(X_{m}\right)$ measure the number of times that the inequality $V_{k}(T)<F_{k}$ is feasible. We can estimate the value of the probability of default as follows:

$$
P_{D}\left(X_{m}\right) \approx \frac{N_{D}\left(X_{m}\right)}{K}
$$

The loss of the portfolio is then obtained as the average of the individual losses:

$$
\left\langle L\left(X_{m}\right)\right\rangle=\frac{1}{K} \sum_{k=1}^{K} L_{k}
$$

We can deduce the following relationship:

$$
\left\langle L\left(X_{m}\right)\right\rangle=P_{D}\left(X_{m}\right)\left(1-\left\langle R\left(X_{m}\right)\right\rangle\right)
$$

The recovery rate is expressed as follows:

$$
\left\langle R\left(X_{m}\right)\right\rangle=1-\frac{\left\langle L\left(X_{m}\right)\right\rangle}{P_{D}\left(X_{m}\right)} \approx 1-\frac{K\left\langle L\left(X_{m}\right)\right\rangle}{N_{D}\left(X_{m}\right)}
$$

Several studies have shown that the number of default $N_{D}\left(X_{m}\right)$ is strictly non-zero. This is justified based on a large portfolio is measured by $\mathrm{K}$. If we based on the evolution of a portfolio, we can obtain different values for the market return $\left(X_{m}\right)$, the number of defaults $N_{D}\left(X_{m}\right)$, the probability of default $P_{D}\left(X_{m}\right)$ and the recovery rate $\left\langle R\left(X_{m}\right)\right\rangle$.

\section{Data and empirical model}


In this section, we identify the sources of our data. We present the data itself and describe the regression model. Finally, we use to investigate the relation of dependence between the probability of default and the recovery rate.

\subsection{Data}

In this paper, we employ the indicator of 17 banks quoted in the Athens Exchange of through the period from January 02, 2006 to December 31, 2012. The list of banks included in this study is presented in the Table 2. The balance sheet data is collected from Statistical Bulletin of The Athens Exchange. In this study, we use the regression analysis to identify the dependence between PD and RR. The descriptive statistics applies to find the mean, the maximum, the minimum and standard deviation, Skweenes and Kurtosis of those variables. The Pearson correlation tests applied to deal with the problems.

Table 2: List of Banks

\begin{tabular}{|c|c|}
\hline Name of Bank & The study period \\
\hline ALPHA BANK (KO) & $02 / 01 / 2006-31 / 12 / 2012$ \\
\hline ASPIS BANK (KO) & $02 / 01 / 2006-30 / 06 / 2010$ \\
\hline ATTICA BANK (KO) & $02 / 01 / 2006-31 / 12 / 2012$ \\
\hline BANK OF CYPRUS (CR) & $02 / 01 / 2006-31 / 12 / 2012$ \\
\hline BANK OF GREECE (CR) & $02 / 01 / 2006-31 / 12 / 2012$ \\
\hline EГNATIA BANK (KO) & $02 / 01 / 2006-20 / 09 / 2007$ \\
\hline EГNATIA BANK (ПО) & $02 / 01 / 2006-20 / 08 / 2007$ \\
\hline EMPORIKI BANK (CR) & $02 / 01 / 2006-29 / 04 / 2011$ \\
\hline EUROBANK EFG (KO) & $02 / 01 / 2006-31 / 12 / 2012$ \\
\hline GENIKI BANK (CR) & $02 / 01 / 2006-31 / 12 / 2012$ \\
\hline MARFIN EGNATIA BANK (CR) & $02 / 01 / 2008-31 / 03 / 2011$ \\
\hline MARFIN FINANCIAL GROUP (KO) & $02 / 01 / 2006-30 / 03 / 2007$ \\
\hline MARFIN POPULAR BANK (KO) & $02 / 01 / 2008-11 / 04 / 2012$ \\
\hline NATIONAL BANK (CR) & $02 / 01 / 2006-31 / 12 / 2012$ \\
\hline PIRAEUS BANK (CR) & $02 / 01 / 2006-31 / 12 / 2012$ \\
\hline PROTON BANK S,A, (CR) & $02 / 01 / 2006-31 / 12 / 2012$ \\
\hline TT HELLENIC POSTBANK (CR) & $02 / 01 / 2008-30 / 12 / 2011$ \\
\hline
\end{tabular}

\subsection{Econometric methodology}

In this study, we utilize two econometric techniques to quantify the dependence between the probability of default and recovery rate. Those techniques are the Bootstrapped Quantile Regression and the Simultaneous Quantile Regression.

Then, we employ these two techniques because the parameter quantile regression provides an estimate of the change in a specific quantile of the response variable produced by a unit change in the predictor. 


\subsection{Empirical model}

In our study, we use two models who describe the dependence between the probability of default and the recovery rate. We estimate the probability of default in function of seven variables. All these variables are explained in follows (Frye, 2000; Altman, 2001; Gordy, 2001; Altman et al., 2002; Altman et al., 2005; Bruche and Gonzalez-Aguado, 2008; Becker, 2013). The probability of default is estimated by the model presented as follow:

\section{(Equation 1)}

$$
P D_{t}=f\left(R R_{t}, N D_{t}, L_{t}, \text { Dummy }_{t}, \text { Dummy } 2_{t}, \text { Dummy }_{t}\right)
$$

When, $\boldsymbol{P} \boldsymbol{D}_{\boldsymbol{t}}$ denotes the probability of default at the moment t, $\boldsymbol{R} \boldsymbol{R}_{\boldsymbol{t}}$ denotes the recovery rate at the moment $\mathrm{t}, \boldsymbol{N} \boldsymbol{D}_{\boldsymbol{t}}$ denotes the number of default at the moment $\mathrm{t}$ and $\boldsymbol{L}_{\boldsymbol{t}}$ denotes the expected value of losses at the moment t. Dummy $\mathbf{1}_{\boldsymbol{t}}$ indicates that a new firm is listed in the Athens Exchange at the moment t. This variable that takes the value 1 when a new firm is listed in the Athens Exchange and takes 0 in the opposite occur. Dummy $\boldsymbol{2}_{\boldsymbol{t}}$ indicates that a new firm is going out of the Athens Exchange at the moment t. This variable that takes the value 1 when a new firm is going out of the Athens Exchange and takes 0 in the opposite

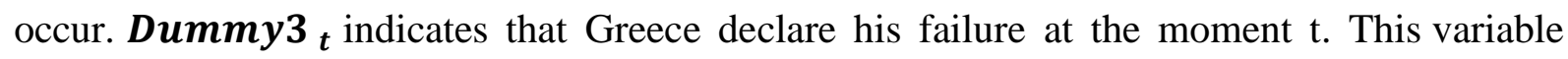
takes the value 1 after the date of failure and 0 before the date of failure. The employed data are daily and which are collected from the publication of the Athens Exchange.

\section{Results and Discussion}

Within the framework of this paper, we present a descriptive statistics analysis of the various variables used in all estimations. These variables are utilized to estimate the dependence between probability of default and recovery rate.

First of all, the number of the observations is limited to 1748 observations concerning the two models. Table 3 shows all the descriptive statistics (mean, max, min, the standard deviation, the Skewness and the Kurtosis) relative to variables used in the different estimation of the variable PD.

According to this Table, we can remark that the maximum of probability of default is equal to 0.7606353 through the period of study. However, the maximum of recovery rate is equal to 1 . This finding implies that the probability of default can be absorbed by the recovery rate. 
For the two statistics of skewness (asymmetry) and kurtosis (leptokurtic), we can observe that the two variables used in our study are characterized by non-normal distribution. The positive sign of the skewness coefficients indicate that the variable is skewed to the right and it is far from being symmetric for all variables in except of the recovery rate and the expected value of losses. Also, the Kurtosis coefficients confirm that the leptokurtic for all variables used in this study show the existence of a high peak or a fat-tailed in their volatilities.

Table 3: Descriptive Statistics

\begin{tabular}{lccccccc}
\hline \hline Variable & Obs & Mean & Std Div & Min & Max & Skewness & Kurtosis \\
\hline \hline PD & 1748 & 0.5007853 & 0.0845174 & 0.1545267 & 0.7606353 & 0.2988851 & 2.873225 \\
RR & 1748 & 0.7433242 & 0.0993225 & 0.0076826 & 1 & -0.0383176 & 2.363317 \\
ND & 1748 & 6.653638 & 1.326654 & -0.0109848 & 10.00634 & 0.1338035 & 2.517658 \\
L & 1748 & -0.109574 & 0.6235335 & 0.4428743 & 0.4199632 & -6.181387 & 104.6915 \\
Dummy1 & 1748 & 0.0005721 & 0.0239182 & 0 & 1 & 41.7732 & 1746.001 \\
Dummy2 & 1748 & 0.0040046 & 0.063173 & 0 & 1 & 15.70727 & 247.7183 \\
Dummy3 & 1748 & 0.4302059 & 0.4952465 & 0 & 1 & 0.2819365 & 1.079488 \\
\hline \hline
\end{tabular}

Then, we employ two types of estimations, such as, the Bootstrapped Quantile Regression and the Simultaneous Quantile Regression. The choice of the two methodologies is justified by the objective of this paper. Then, the purpose of this study is to examine the correlation among the Probability of Default and the Recovery Rate. Those econometric techniques allow describing the dependence between tow variables based on their volatilities.

Figure 1 shows the evolution of the probability of default and the recovery rate for each year (2006-2012). In Figure 2, we present the volatility of the PD and the RR through the period from January 02, 2006 to December 31, 2012.

Figure 1: The volatility of the PD and the RR (by year) 

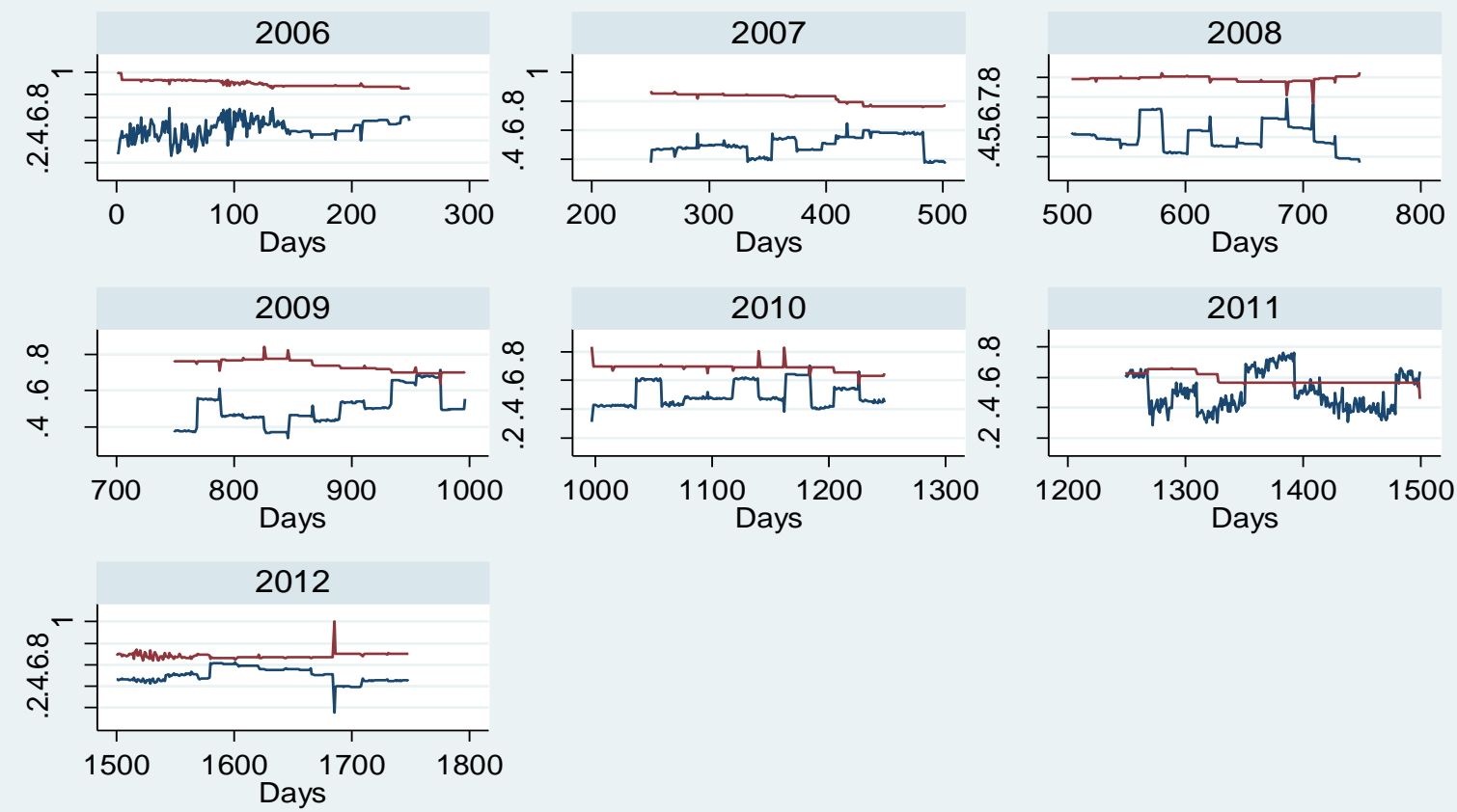

Days

Probability of Default $\longrightarrow$ Recovery Rate

Figure 2: The volatility of the PD and the RR

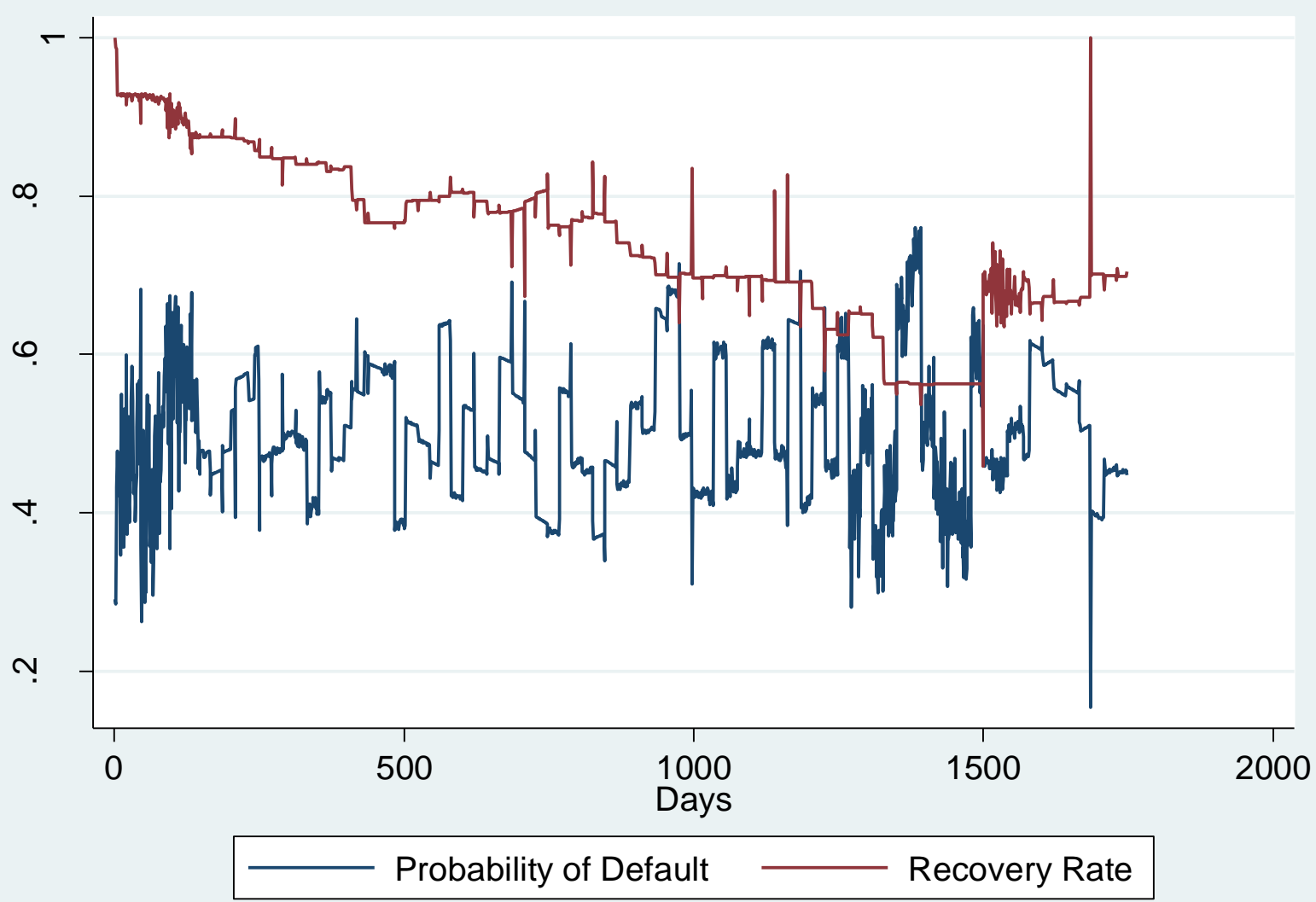


In this study, we made a test of the correlation between the various utilized variables. Table 4 reports the empirical results relative to the correlation. So, the empirical findings present that all the coefficient of correlation of Pearson does not exceed the limit of tolerance of 0.7 , so it does not cause problems during the estimation of the model which measures the PD.

Table 4: The matrix of correlation

\begin{tabular}{lccccccc}
\hline \hline & PD & RR & ND & L & Dummy1 & Dummy2 & Dummy3 \\
\hline PD & 1.0000 & & & & & & \\
RR & -0.1116 & 1.0000 & & & & & \\
& $(0.0000)^{*}$ & & & & & & \\
ND & 0.8495 & 0.1209 & 1.0000 & & & & \\
& $(0.0000)^{*}$ & $(0.0000)^{*}$ & & & & & \\
L & 0.1059 & 0.1264 & 0.5142 & 1.0000 & & & \\
Dummy1 & $(0.0000)^{*}$ & $(0.0000)^{*}$ & $(0.0000)^{*}$ & & & & \\
& 0.0057 & 0.0115 & 0.0115 & 0.0072 & 1.0000 & & \\
Dummy2 & $(0.8132)$ & $(0.6306)$ & $(0.6311)$ & $(0.7621)$ & & & \\
& 0.0272 & -0.0330 & 0.0343 & 0.0269 & -0.0015 & 1.0000 & \\
Dummy3 & $(0.2564)$ & $(0.1680)$ & $(0.1520)$ & $(0.2611)$ & $(0.9495)$ & & \\
& 00016 & -0.7990 & -0.3087 & -0.3878 & -0.0208 & 0.0181 & 1.0000 \\
\hline \hline & $(0.9469)$ & $(0.0000)^{*}$ & $(0.0000)^{*}$ & $(0.0000)^{*}$ & $(0.3850)$ & $(0.4498)$ & \\
\hline
\end{tabular}

Also, we conduct an unit root test for time series. Thus, we employ the Augmented-DickeyFuller and Phillips-Perron test. According to the results shown in Table 5 and Table 6, we find that all the calculated values of the t-student or t-statistical values are inferior to the critical thresholds of $1 \%, 5 \%$ and $10 \%$. In this case, all the variables employed in this paper are stationary.

Table 5: The unit root test of Augmented-Dickey-Fuller

\begin{tabular}{|l|l|l|l|l|l|}
\hline Variables & t-statistic & $\begin{array}{l}\text { Critical } \\
\text { value at 1\% }\end{array}$ & $\begin{array}{l}\text { Critical value } \\
\text { at 5\% }\end{array}$ & $\begin{array}{l}\text { Critical value } \\
\text { at 10\% }\end{array}$ & The hypothesis rejected \\
\hline DP & -12.106 & -3.430 & -2.860 & -2.570 & $\begin{array}{l}\text { H0: presence of unit root. So } \\
\text { the variable is stationary }\end{array}$ \\
\hline RR & -4.256 & -3.430 & -2.860 & -2.570 & $\begin{array}{l}\text { H0: presence of unit root. So } \\
\text { the variable is stationary }\end{array}$ \\
\hline ND & -10.285 & -3.430 & -2.860 & -2.570 & $\begin{array}{l}\text { H0: presence of unit root. So } \\
\text { the variable is stationary }\end{array}$ \\
\hline L & -13.770 & -3.430 & -2.860 & -2.570 & $\begin{array}{l}\text { H0: presence of unit root. So } \\
\text { the variable is stationary }\end{array}$ \\
\hline Dummy1 & -41.797 & -3.430 & -2.860 & -2.570 & $\begin{array}{l}\text { H0: presence of unit root. So } \\
\text { the variable is stationary }\end{array}$ \\
\hline Dummy2 & -41.942 & -3.430 & -2.860 & -2.570 & $\begin{array}{l}\text { H0: presence of unit root. So } \\
\text { the variable is stationary }\end{array}$ \\
\hline Dummy3 & -12.868 & -3.430 & -2.860 & -2.570 & $\begin{array}{l}\text { H0: presence of unit root. So } \\
\text { the variable is stationary }\end{array}$ \\
\hline
\end{tabular}

Table 6: The unit root test of Phillips-Perron

\begin{tabular}{|l|l|l|l|l|l|}
\hline Variables & t-statistic & $\begin{array}{l}\text { Critical } \\
\text { value at 1\% }\end{array}$ & $\begin{array}{l}\text { Critical } \\
\text { value at 5\% }\end{array}$ & $\begin{array}{l}\text { Critical } \\
\text { value at 10\% }\end{array}$ & The hypothesis rejected \\
\hline DP & -233.223 & -20.700 & -14.100 & -11.300 & $\begin{array}{l}\text { H0: presence of unit root. } \\
\text { So the variable is stationary }\end{array}$ \\
\hline RR & -297.631 & -20.700 & -14.100 & -11.300 & H0: presence of unit root. \\
\hline
\end{tabular}




\begin{tabular}{|l|l|l|l|l|l|}
\hline & & & & & So the variable is stationary \\
\hline ND & -153.469 & -20.700 & -14.100 & -11.300 & $\begin{array}{l}\text { H0: presence of unit root. } \\
\text { So the variable is stationary }\end{array}$ \\
\hline L & -33.607 & -20.700 & -14.100 & -11.300 & $\begin{array}{l}\text { H0: presence of unit root. } \\
\text { So the variable is stationary }\end{array}$ \\
\hline Dummy1 & -1745.365 & -20.700 & -14.100 & -11.300 & $\begin{array}{l}\text { H0: presence of unit root. } \\
\text { So the variable is stationary }\end{array}$ \\
\hline Dummy2 & -1735.363 & -20.700 & -14.100 & -11.300 & $\begin{array}{l}\text { H0: presence of unit root. } \\
\text { So the variable is stationary }\end{array}$ \\
\hline Dummy3 & -1214.754 & -20.700 & -14.100 & -11.300 & $\begin{array}{l}\text { H0: presence of unit root. } \\
\text { So the variable is stationary }\end{array}$ \\
\hline
\end{tabular}

To pursue our empirical analysis, we estimate the variables PD in Table 7 and the Table 8. So, we estimate the variable PD by using 8 estimations for each of both variables and by using two econometric techniques.

In the table 7, we employ the Bootstrapped Quantile Regression. Then, we notice that all the values of the statistical Pseudo- $\mathrm{R}^{2}$ are almost equal to 0.80 in all estimates. So, we can conclude that the estimated model is characterized by a good linear adjustment.

In our model, the probability of default is estimated based on other explicative variables. The results of estimation are presented in Table 7.

This table summarizes all estimations relative to the model (PD), we show that there are four significant variables with different thresholds. The first one, it is the variable RR, is statistically significant and negative in a $1 \%$ threshold in four estimations (1, 2, 3 and 5), in a $5 \%$ threshold in the sixth estimation and in a $10 \%$ threshold in the last estimations. In this context, the variable RR has a negative impact on the probability of default of the Greek banks. Then, when the recovery rate increases, the banks have profit to supply an important exposure to failure. We can conclude that a high recovery rate allow to absorb losses incurred by banks in Greece.

The variable ND is statistically significant and positive in a $1 \%$ threshold in all estimations. The number of default of banks affects their probability of default. Thus, the high numbers of default reflect that the probability of default is high.

The variable $\mathrm{L}$ (the expected losses) is statistically significant and negative in a 5\% threshold only in all estimation. This confirms the literature, because the high value of the expected losses allows the bank to minimize their probability of default in future.

For the three dummy variables used in our study, we conclude that only the dummy1 variable is significant in 5\% threshold in the estimation 2 and 5. This variable affects negatively the probability of default. Then, the entry of a new bank in the Athens Exchange leads to the 
minimization of the probability of default of the existing banks in the financial market of Greece.

In the table 8, we utilize the Simultaneous Quantile Regression. Then, we find that all the values of the statistical Pseudo- $\mathrm{R}^{2}$ are equal to 0.80 in all estimates. Then, we can remark that the estimated model is characterized by a good linear adjustment.

In the model (PD), the probability of default is estimated based on other explicative variables. The results of estimation are presented in Table 7.

After employing the second econometric techniques (Simultaneous Quantile Regression), we conclude that all the results have almost the same significance thresholds then the first econometric methodology. Then, for the two econometric techniques the impact of different variables remains the same.

Empirically, we can find that the probability of default is inversely related to the recovery rate. The recovery rate is not constant; it decreases with increasing of the probability of default. This empirical finding is confirmed by these figures follows. On these figures we presented the volatility of probability of default and recovery rate of all Greek banks and by year. The dependence between PD and RR is justified by the correlation coefficients of Pearson who presented in Table 4.

The dependence between the Probability of Default and the Recovery rate of all banks is shows in figure 3 , figure 4 , figure 5, figure 6 , figure 7, figure 8 and figure 9 . All these Figure shows the dependence between the Probability of Default and the Recovery rate of all banks by years (see, figure 3 , figure 4 , figure 5 , figure 6 , figure 7 , figure 8 and figure 9 ) 
Table 7: Estimation by Bootstrapped Quantile Regression

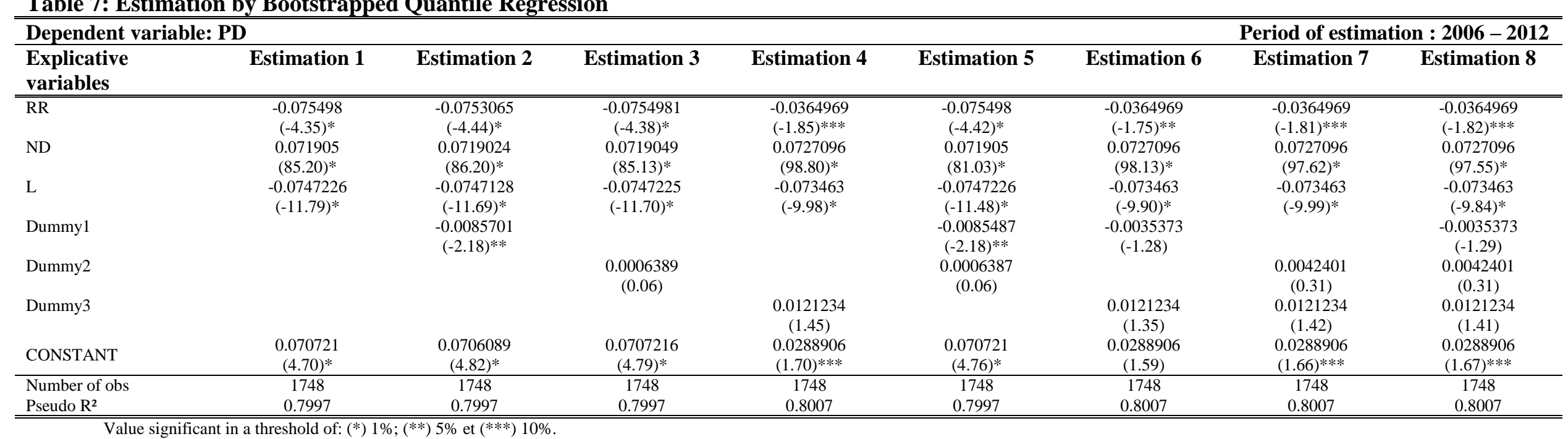

Table 8: Estimation by Simultaneous Quantile Regression

\begin{tabular}{|c|c|c|c|c|c|c|c|c|}
\hline \multicolumn{7}{|c|}{ Dependent variable: PD } & \multicolumn{2}{|c|}{ Period of estimation : $2006-2012$} \\
\hline $\begin{array}{l}\text { Explicative } \\
\text { variables }\end{array}$ & Estimation 1 & Estimation 2 & Estimation 3 & Estimation 4 & Estimation 5 & Estimation 6 & Estimation 7 & Estimation 8 \\
\hline$\overline{\mathrm{RR}}$ & $\begin{array}{c}-0.075498 \\
(-4.41)^{*}\end{array}$ & $\begin{array}{c}-0.0753065 \\
(-4.23)^{*}\end{array}$ & $\begin{array}{c}-0.0754981 \\
(-4.20)^{*}\end{array}$ & $\begin{array}{l}-0.0365789 \\
(-1.84)^{* * *}\end{array}$ & $\begin{array}{c}-0.075498 \\
(-4.37)^{*}\end{array}$ & $\begin{array}{c}-0.0365789 \\
(-1.57)\end{array}$ & $\begin{array}{c}-0.0365868 \\
(-1.91)^{* * *}\end{array}$ & $\begin{array}{l}-0.0365789 \\
(-1.83)^{* * *}\end{array}$ \\
\hline ND & $\begin{array}{l}0.071905 \\
(83.62)^{*}\end{array}$ & $\begin{array}{c}0.0719024 \\
(82.21)^{*}\end{array}$ & $\begin{array}{c}0.0719049 \\
(84.06)^{*}\end{array}$ & $\begin{array}{l}0.0727134 \\
(100.93)^{*}\end{array}$ & $\begin{array}{l}0.071905 \\
(82.91)^{*}\end{array}$ & $\begin{array}{c}0.0727134 \\
(46.53)^{*}\end{array}$ & $\begin{array}{l}0.0727117 \\
(99.74)^{*}\end{array}$ & $\begin{array}{c}0.0727134 \\
(96.00)^{*}\end{array}$ \\
\hline $\mathrm{L}$ & $\begin{array}{c}-0.0747226 \\
(-11.71)^{*}\end{array}$ & $\begin{array}{c}-0.0747128 \\
(-11.56)^{*}\end{array}$ & $\begin{array}{c}-0.0747225 \\
(-11.89)^{*}\end{array}$ & $\begin{array}{c}-0.0734714 \\
(-10.03)^{*}\end{array}$ & $\begin{array}{c}-0.0747226 \\
(-11.66)^{*}\end{array}$ & $\begin{array}{c}-0.0734714 \\
(-10.01)^{*}\end{array}$ & $\begin{array}{l}-0.07347 \\
(-10.25)^{*}\end{array}$ & $\begin{array}{c}-0.0734714 \\
(-9.98)^{*}\end{array}$ \\
\hline Dummy1 & & $\begin{array}{c}-0.0085701 \\
(-2.20)^{* *}\end{array}$ & & & $\begin{array}{c}-0.0085487 \\
(-2.21)^{* *}\end{array}$ & $\begin{array}{c}-0.0035433 \\
(-0.80)\end{array}$ & & $\begin{array}{c}-0.0035433 \\
(-1.27)\end{array}$ \\
\hline Dummy2 & & & $\begin{array}{c}0.0006389 \\
(0.05)\end{array}$ & & $\begin{array}{c}0.0006387 \\
(0.05)\end{array}$ & & $\begin{array}{c}0.0042446 \\
(0.30)\end{array}$ & $\begin{array}{c}0.0042409 \\
(0.31)\end{array}$ \\
\hline Dummy3 & & & & $\begin{array}{c}0.0121102 \\
(1.37)\end{array}$ & & $\begin{array}{l}0.0121102 \\
(1.42)\end{array}$ & $\begin{array}{c}0.0121108 \\
\quad(1.42)\end{array}$ & $\begin{array}{c}0.0121102 \\
\quad(1.41)\end{array}$ \\
\hline CONSTANT & $\begin{array}{c}0.070721 \\
(4.75)^{*} \\
\end{array}$ & $\begin{array}{c}0.0706089 \\
(4.61)^{*}\end{array}$ & $\begin{array}{c}0.0707216 \\
(4.79)^{*}\end{array}$ & $\begin{array}{c}0.0289338 \\
(1.66)^{* * * *}\end{array}$ & $\begin{array}{c}0.070721 \\
(4.72)^{*} \\
\end{array}$ & $\begin{array}{c}0.0289338 \\
(1.61)\end{array}$ & $\begin{array}{c}0.0289489 \\
(1.73)^{* * * *}\end{array}$ & $\begin{array}{c}0.0289338 \\
(1.64)^{* * * *}\end{array}$ \\
\hline $\begin{array}{l}\text { Number of obs } \\
\text { Pseudo } R^{2}\end{array}$ & $\begin{array}{c}1748 \\
0.8021\end{array}$ & $\begin{array}{c}1748 \\
0.8022\end{array}$ & $\begin{array}{c}1748 \\
0.8031\end{array}$ & $\begin{array}{c}1748 \\
0.8022\end{array}$ & $\begin{array}{c}1748 \\
0.8022\end{array}$ & $\begin{array}{c}1748 \\
0.8032\end{array}$ & $\begin{array}{c}1748 \\
0.8032\end{array}$ & $\begin{array}{c}1748 \\
0.8032\end{array}$ \\
\hline
\end{tabular}

Value significant in a threshold of: (*) 1\%; (**) 5\% et (***) $10 \%$ 
Figure 3: The volatility of the PD and the RR in 2006 (by Banks)

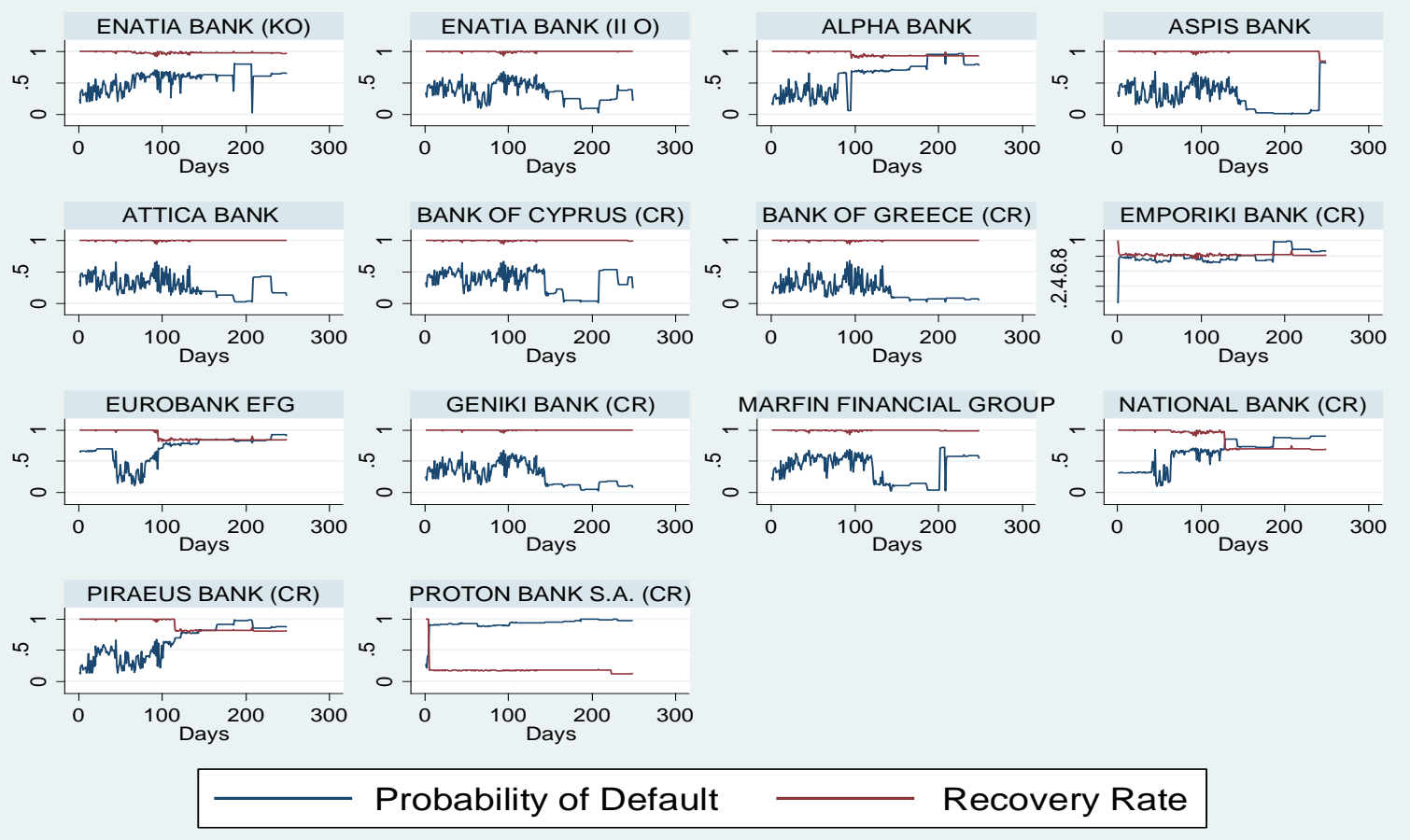

Figure 4: The volatility of the PD and the RR in 2007 (by Banks)

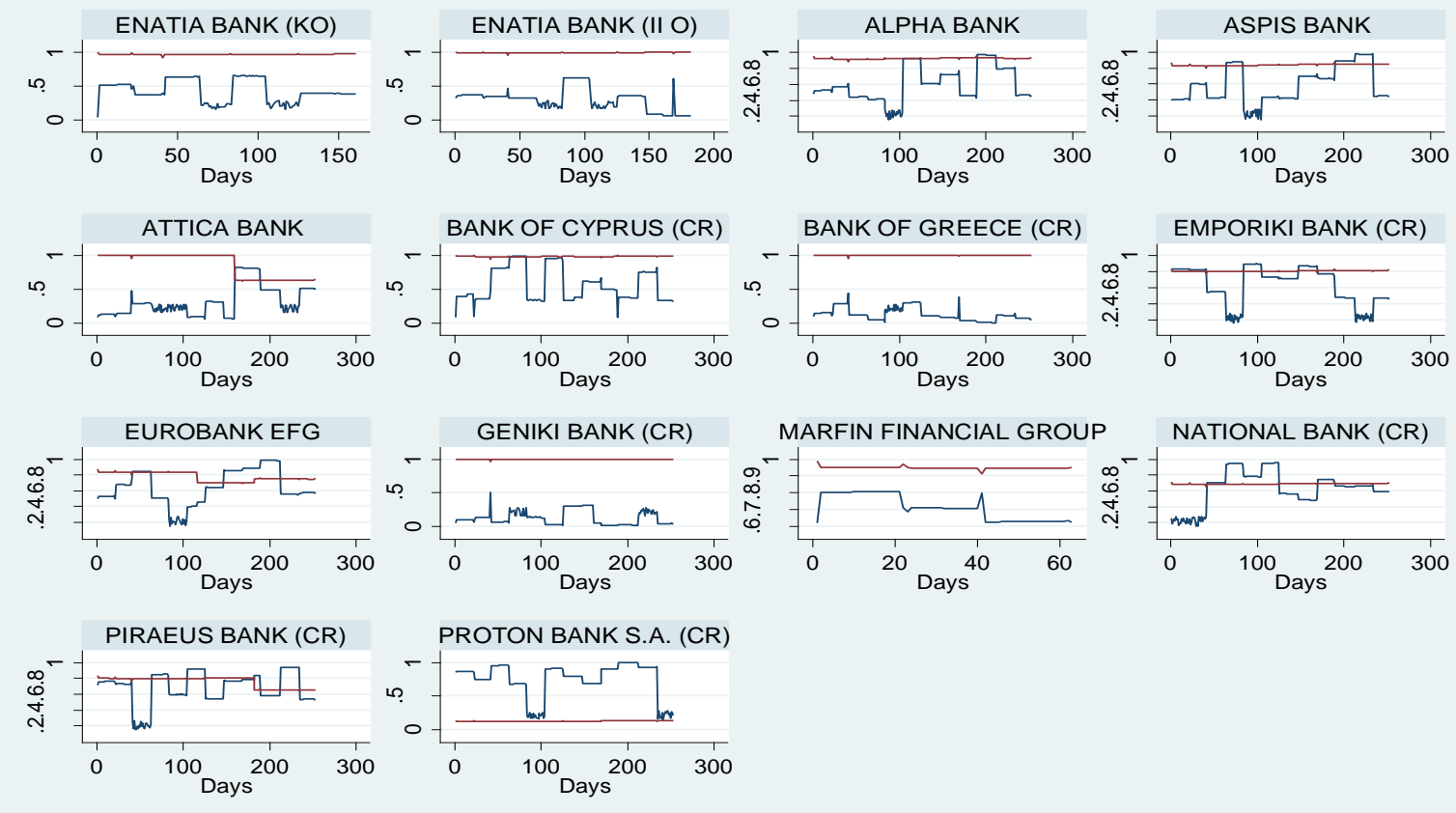

Probability of Default

Recovery Rate 
Figure 5: The volatility of the PD and the RR in 2008 (by Banks)

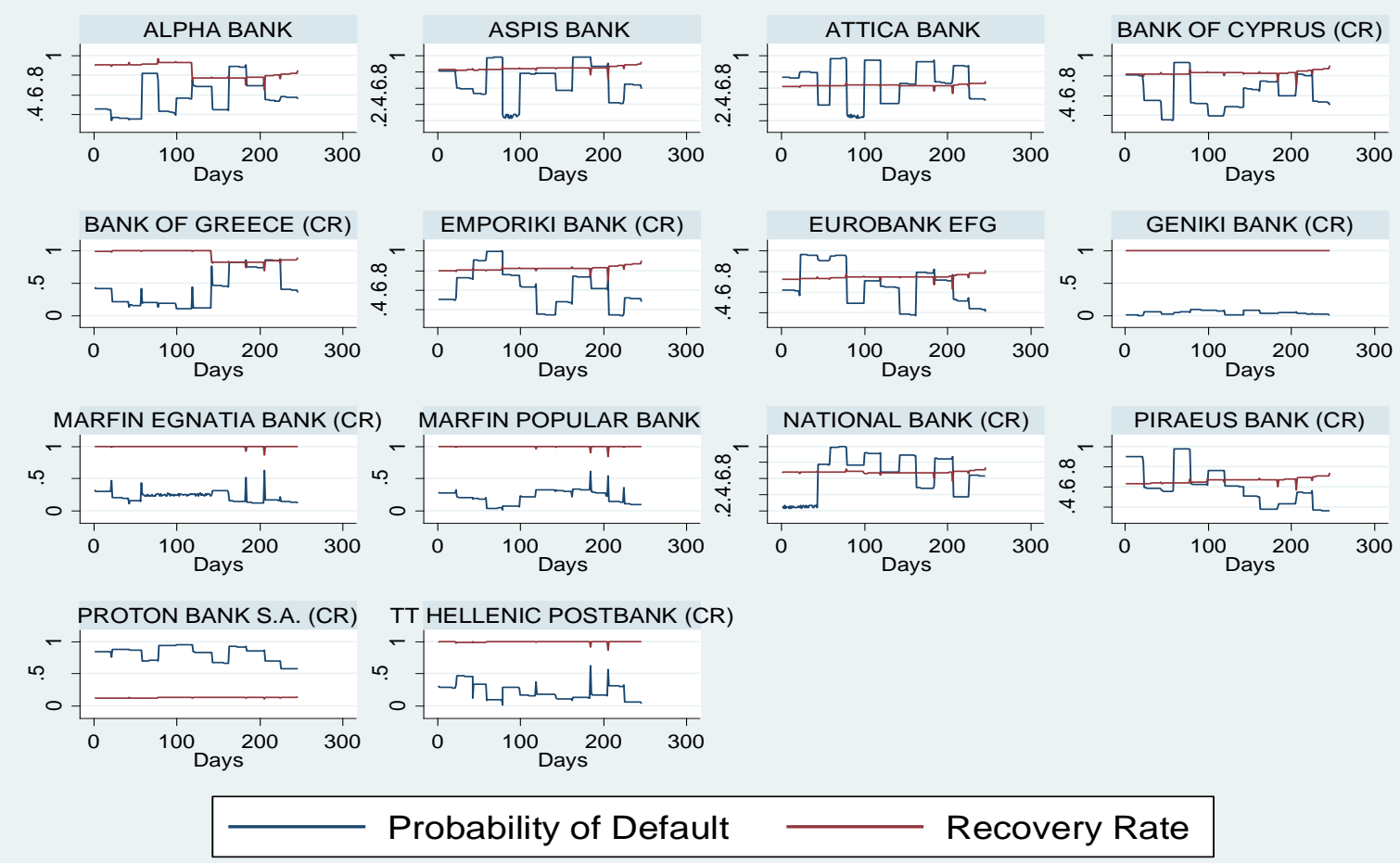

\section{Figure 6: The volatility of the PD and the RR in 2009 (by Banks)}
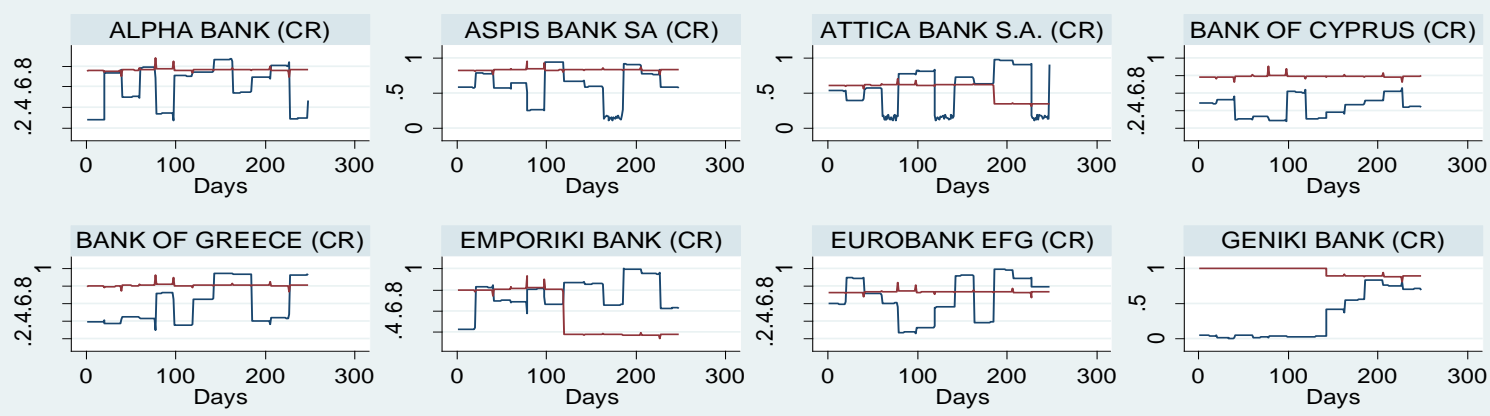

MARFIN EGNATIA BANK (CR) MARFIN POPULAR BANK (CR) NATIONAL BANK (CR)
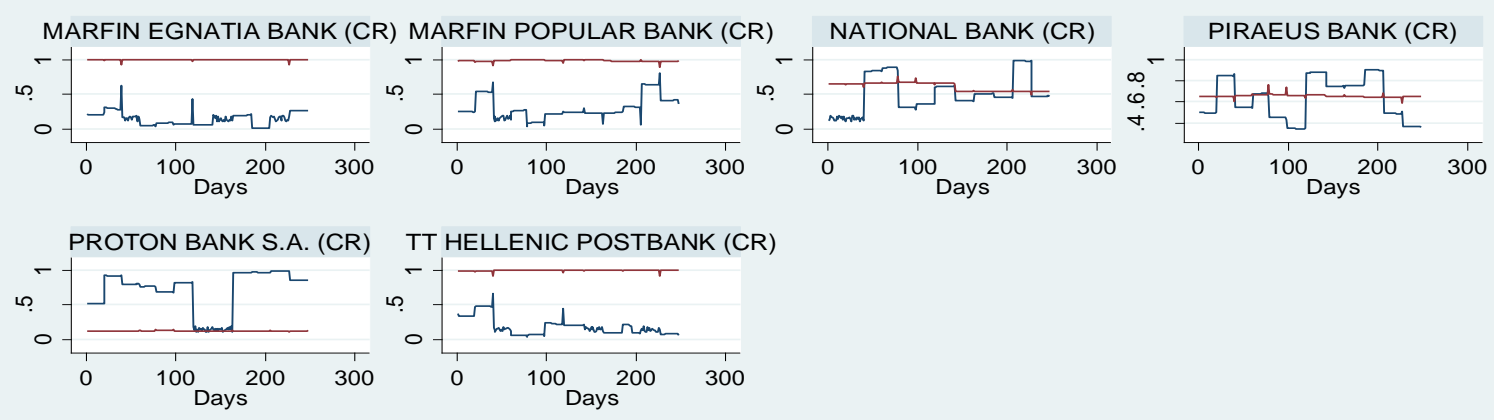

Probability of Default

Recovery Rate 
Figure 7: The volatility of the PD and the RR in 2010 (by Banks)
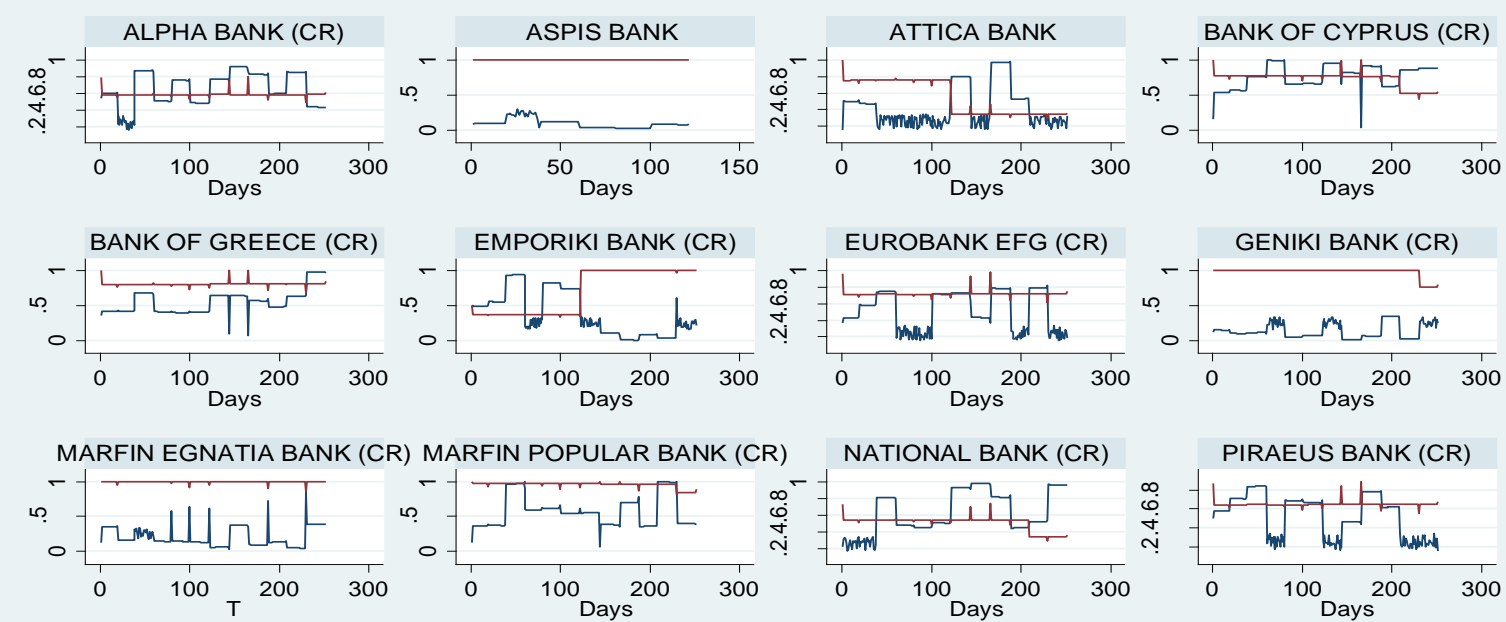

PIRAEUS BANK (CR)
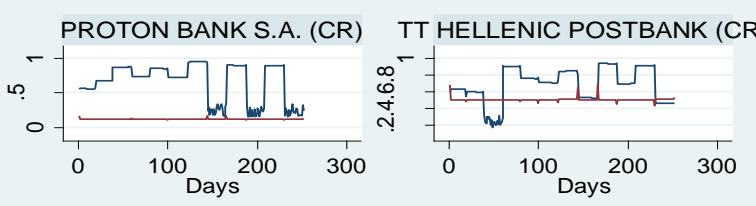

- Probability of Default $\quad$ Recovery Rate

\section{Figure 8: The volatility of the PD and the RR in 2011 (by Banks)}
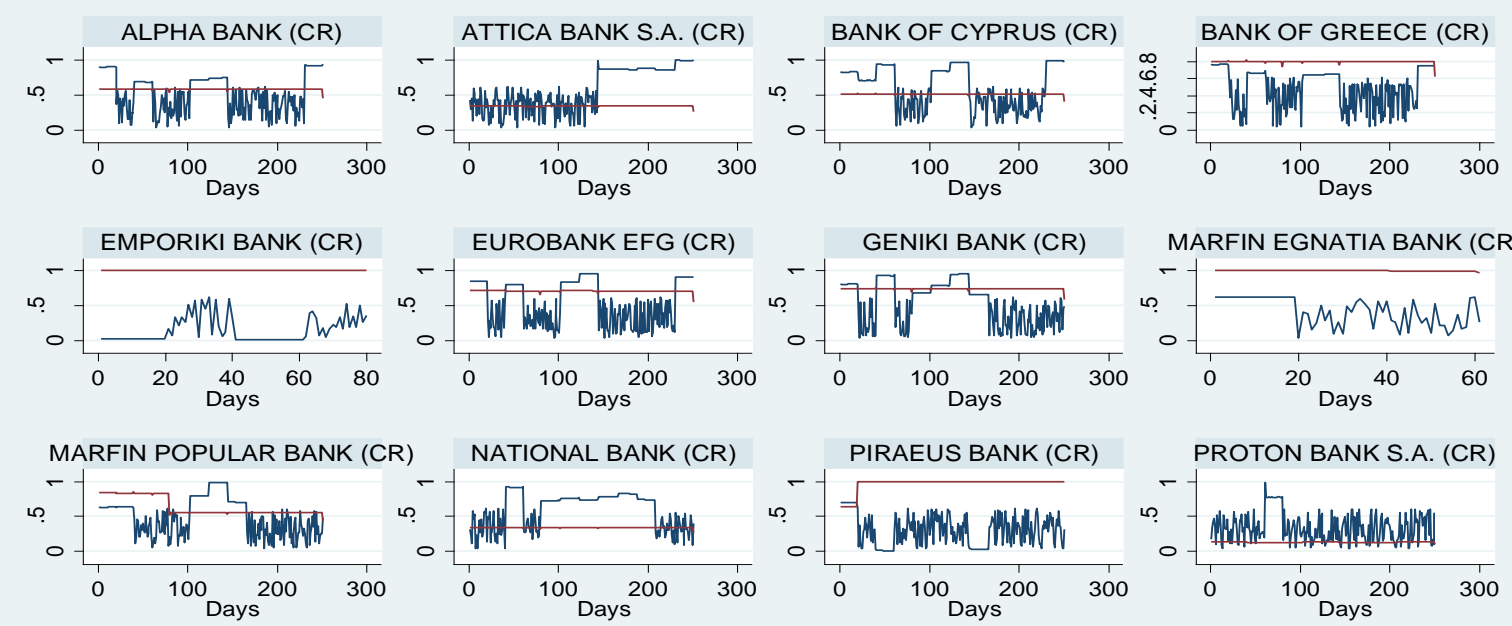

PROTON BANK S.A. (CR)

TT HELLENIC POSTBANK (CR)

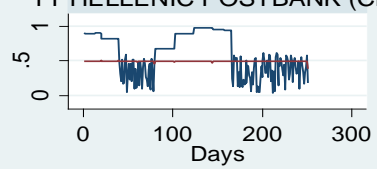

Probability of Default $\quad$ Recovery Rate




\section{Figure 9: The volatility of the PD and the RR in 2012 (by Banks)}
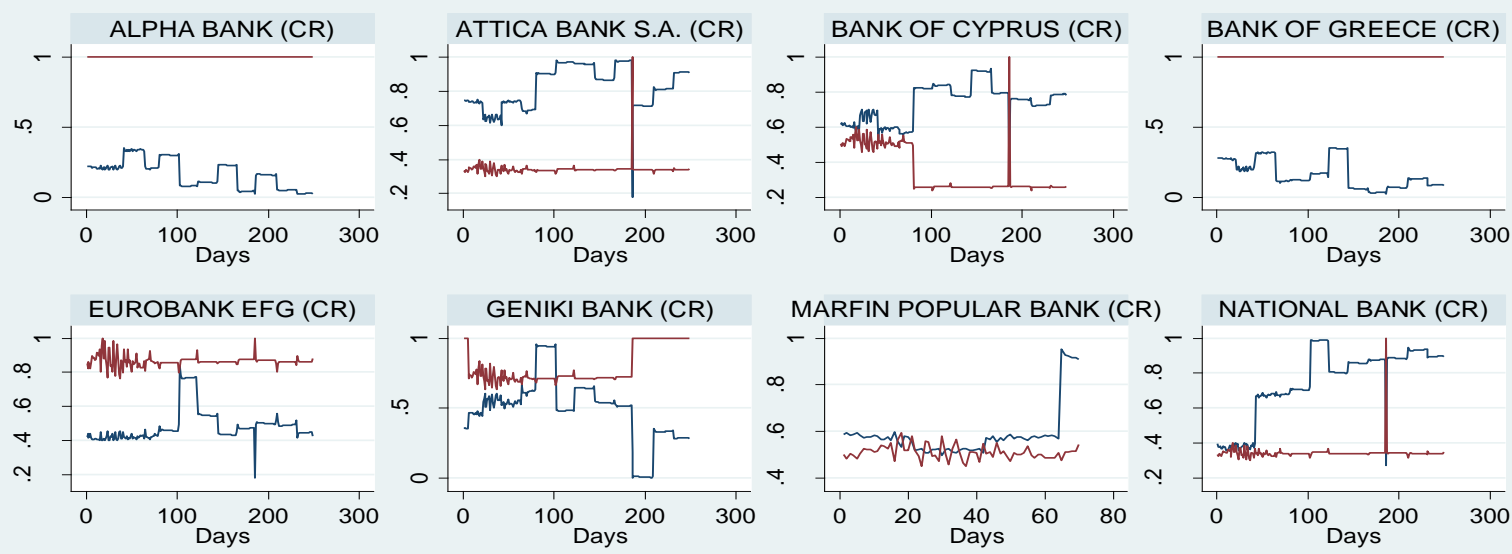

NATIONAL BANK (CR)
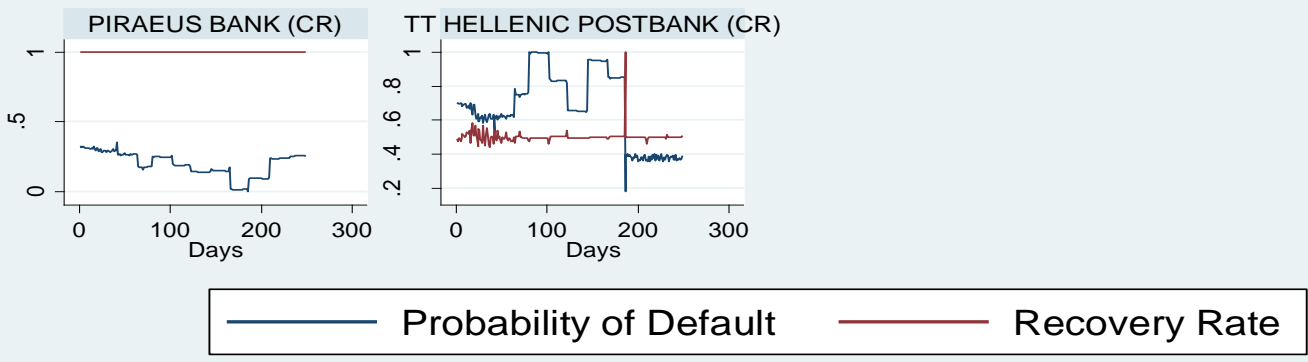

We, also, use a Kruskal-Wallis equality-of-populations rank test. The Kruskal-Wallis oneway analysis of variance by ranks is a non-parametric method for testing whether samples originate from the same distribution. It is employ for comparing more than two samples that are independent, or not related. The parametric equivalent of the Kruskal-Wallis test is the one-way analysis of variance (ANOVA). The results of this test can accept the hypothesis H0. ie the average of the different types of sample studied are not significantly different (Mean Rank $=6<$ Index Kruskal-Wallis = 6,713).

We calculate also the Value-at-Risk on four confidence level chosen (see, Table 9).

Table 9: The VaR results

\begin{tabular}{l|l}
\hline Confidence level & VaR \\
\hline $95 \%$ & 0,3641361 \\
\hline $99 \%$ & 0,3641539 \\
\hline $99.5 \%$ & 0,3756432 \\
\hline $99.9 \%$ & 0,3778987 \\
\hline \hline
\end{tabular}

In recession periods, the number of defaulting banks or firms in generally rises. On top of this, the average amount recovered on the bonds of defaulting banks tends to decrease. Our paper purpose an econometric model in which this joint time-variation in default rates and 
recovery rate distribution by a quantile regression, which given the importance if the volatilities.

\section{Conclusion}

The dependence between the probability of default and the recovery rate has a crucial influence on large credit portfolio losses. Thus, the probability of default and the recovery rate are often modeled independently in current credit risk models: KMV model, CreditMetrics model, CreditRisk+ and Credit Portfolio View.

In this paper, we utilize the bootstrapped quantile regression and the simultaneous quantile regression for a sample composed of 17 Greek banks listed in Athens Exchange over the period from January 02, 2006 to December 31, 2012. To estimate this dependence, we utilize 7 indicators such as; the probability of default, the recovery rate, the number of defaults, the expected value of losses, the growth rate of GDP in Greece and three dummy variables (the exit of another firm of the Athens Exchange, the new firm is listed in the Athens exchange and the date of the failure of Greece)..

Finally, we conclude that the probability of default and the recovery rate are inversely related. This result is confirmed by those table and figure presented in the fourth section.

Based on the results found in this study, the banks are obliged to maximize their recovery rate to reduce their probability of default.

\section{References}

Ali, A. and Daly, K. (2010). Macroeconomic determinants of credit risk: Recent evidence from a cross country study. International Review of Financial Analysis, 19, pp. 165-171.

Altman, E.I. (1989). Measuring corporate bond mortality and performance. Journal of Finance, 44, pp. 909-922.

Altman, E.I., Brady, P., Resti, A. and Sironi, A. (2005). The link between default and recovery rates: effects on the procyclicality of regulation capital ratios: Theory, Empirical evidence, and implications. Journal of Business, 78(6), pp. 2203-2227.

Bensoussan, A., Crouhy, M. and Galai, D. (1995). Stochastic equity volatility related to the leverage effect II: Valuation of European equity options and warrants. Applied Mathematical Finance, 2, pp. 43-59. 
Berry, M., Burmeister, E. and McElroy, M. (1998) Sorting our risks using known APT factors. Financial Analysts Journal, 44(2), pp. 29-42.

Crouhy, M., Galai, D. and Mark, R. (2000). A comparative analysis of current credit risk models. Journal of Banking \& Finance, 24, pp. 59-117.

Duffie, D. and Singleton, K.J. (1999). Modeling the term structures of defaultable bonds. Review of Financial Studies, 12, pp. 687-720.

Figlewski, S., Frydman, H. and Liang, W. (2012). Modeling the effect of macroeconomic factors on corporate default and credit rating transitions. International Review of Economics and Finance, 21, pp. 87-105.

Grundke, P. (2005). Risk Measurement with Integrated Market and Credit Portfolio Models. Journal of Risk, 7(3), pp. 63-94.

Grundke, P. (2009). Importance sampling for integrated market and credit portfolio models. European Journal of Operational Research, 194, pp. 206-226.

Huang, S.J. and Yu, J. (2010). Bayesian analysis of structural credit risk models with microstructure noises. Journal of Economic Dynamics \& Control, 34, pp. 2259-2272.

Jarrow, R. and Turnbull, S. (1995). Pricing derivatives on financial securities subject to credit risk. The Journal of Finance, 50, pp. 53-85.

Jarrow, R.A., Lando, D. and Yu, F. (2001). Default risk and diversification: theory and applications. Mathematical Finance, 15, pp. 1-26.

Jarrow, R.A. (2011).Credit market equilibrium theory and evidence: Revisiting the structural versus reduced form credit risk model debate. Finance Research Letters, 8, pp. 2-7.

Lee, W.C. (2011). Redefinition of the KMV model's optimal default point based on geneticalgorithms-Evidence from Taiwan. Expert Systems with Applications, 38, pp. 1010710113.

Liao, H.H., Chen, T.K. and Lu, C.W. (2009). Bank credit risk and structural credit models: Agency and information asymmetry perspectives. Journal of Banking \& Finance, 33, pp. $1520-1530$.

Merton, R. (1947). On the pricing of corporate debts: the risk structure of interest rates. Journal of Finance, 29, pp. 449-470. 
Musto, D.K. and Souleles, N.S. (2006). A portfolio view of consumer credit. Journal of Monetary Economics, 53, pp. 59-84.

Tarashev, N. (2010). Measuring portfolio credit risk correctly: Why parameter uncertainly matters. Journal of Banking \& Finance, 34, pp. 2065-2076.

Vetendorpe, A., Ho, N.D., Vetuffel, S. and Dooren, P.V. (2008). On The Parameterization of the CreditRisk+ Model for Estimating Credit Portfolio Risk. Insurance: Mathematics and Economics, 42(2), pp. 736-745.

Wilson, T.C. (1997a). Portfolio credit risk (I). Risk, 10(9), pp. 111-17.

Wilson, T.C. (1997b). Portfolio credit risk (II). Risk, 10(10), pp. 56-61.

Xiaohong, C., Xiaoding, W. and Desheng, W.D. (2010). Credit risk measurement and early warning of SMEs: An empirical study of listed SMEs in China. Decision Support Systems, 4, pp. 301-310.

Zhang, Q. and Wu, M. (2011). Credit Risk Migration Based on Jarrow-Turnbull Model. Systems Engineering Procedia, 2, pp. 49-59. 